\title{
SOIL PHYSICAL CONSTRAINTS AND THEIR EFFECT ON MORPHOLOGICAL CHARACTERS OF COCONUT (Cocos nucifera L. ) ROOTS
}

\author{
By \\ L P Vidhana Arachchi, Yaspa P A J, Mapa R B and Somapala $H .{ }^{l}$
}

\begin{abstract}
The objective of the study was to (1) evaluate land suitability for coconut (cocos nucifera L.) production in relation to soil physical properties, (2) identify the soil physical constraints and (3) study their effect on the morphological adaptation of coconut roots. Soil physical properties were found to be significantly related to coconut yield $\left(R^{2}=81.37 ; p<0.01\right)$. Multiple regression with cluster analysis of soil physical properties vs coconut yield enabled classification of soil series into three major groups namely (a) highly (b) moderately and (c) less productive series. It was observed that the high soil compaction which limited the available water and aeration capacity of soils resulted in retardation of the activity of coconut roots. Water stress due to soil compaction was found to induce production of more inactive roots by suberization and dehydration processes. Scanning electron microscopic image showed that soil compaction and water stress, reduced the cell volume per unit area of the absorption zone and the number of pores in respiratory organs of coconut roots resulting in retardation of water and nutrient absorption, and air exchange processes. This in turn malfunctions of absorption cells and respiratory organs of roots resulted in retardation of growth of coconut seedlings. The practical importance of these findings in formulation of land suitability maps for coconuts is discussed.
\end{abstract}

\section{INTRODUCTION}

The coconut palm (Cocos nucifera L.) is one of the most economically important tree crops in the humid tropical regions of the world. It is grown in different agro-ecological environment with varied soil characteristics. However, only a few of these environments are actually suitable for coconut in all aspects, while others have unsuitable characteristics, particularly soil constraints on tree productivity (Vidhana Arachchi, 1996). The impact of the constraints of climate and soil variability on crop production has recently received much attention both in agricultural and environment journals. Coconut growers pay special attention to soil suitability, because it is important to initiate site specific management practices to optimize crop production (Peries and Thattil, 1998). Therefore, identification of soil constraints related to crop production through land suitability classification is essential. This can be precisely determined if the physiological and morphological adaptation of crop roots with respect to soil constraints is understood.

Amongst the soil constraints, soil physical limitations including moisture deficiency of soils are known as key factors adversely affecting the physiological and morphological adaptation of coconut roots thereby, retardation of the process of gas exchange, water and nutrient absorption (Vidhana Arachchi 1996).

The coconut palm has an adventitious root system as typical of a monocot. The root system concentrates around the bole of the palm and absorption cells and respiratory organs of coconut roots are the major organs involved in the uptake of water and nutrients and exchange of gases in root-soil interface respectively (Vidhana Arachchi, 1996). The role of both respiratory organs and absorption zone in root activities has been discussed by several workers (Davis, 1968; Child, 1974; Jayasekara,

\footnotetext{
${ }^{1}$ Coconut Research Institute, Lunuwila, University of Sri Jayawardenapura, University of Perdeniya, and Department of Agriculture, Sri Lanka, respectively.
} 
1969; Vidhana Arachchi, 1996). However, information on the identification of soil physical constraints through land suitability classification and their effect on the morphological aspects of crop roots are scanty.

The objective of the present investigation was to study the effect of soil physical constraints on morphological features of cocos nucifera roots with a view to evaluating land suitability for coconut cultivation in different agroecological regions of Sri Lanka.

\section{MATERIALS AND METHODS}

\section{Land suitability}

Physical properties and water availability of major soil series were characterized in order to evaluate their effect in coconut production in Sri Lanka. Those were Borupan, Gambura, Wilppattu, Mavillu, Weliketiya and Kalpitiya series which occur in the agroecological region DL3, in the Dry zone. Andigama, Sudu, Madampe, Rathupasa, Ambakele, Welipalassa, Kurunegala, Kuliyapitiya, Maho are occupied in IL1 and Wariyapola series occupies in IL3 in the Intermediate zone. . Melsiripura series occupies the agro-ecological region IM3 in the Intermediate zone. Furthermore, Pallama, Boralu and Katunayake series occupy the agro-ecological regions WL3 and WL4 in the Wet zone respectively within the coconut triangle in Sri Lanka (Somasiri et al., 1994).

Physical properties and water availability of major soil series were characterized in order to evaluate their effect on coconut production in Sri Lanka. A brief description of major soil series used for this study is indicated in Table 1.

Profile description of all soil series were carried out according to the guidelines proposed by FAO (1977). Four soil profiles $(1.0 \times 1.5 \times 1.5 \mathrm{~m})$ for each soil series were used for description and obtained samples analysis of soil physical properties such as total available water (TAW) retention for effective rooting depth, bulk density (BD), macroporosity (Macp), microporosity (Micp), proportion of macro to micropores, sand, silt and clay content.

A distance of $4 \mathrm{~km}$ between each pit of a given soil series was considered in the selection of locations for pit excavation for high precession. Regression models for dependent variables of soil physical properties in respect to coconut yields were computed using the maximum R2 improvement by step-wise regression. Finally, soil series were categorized according to their yield performance. For this purpose the data were analyzed by the SAS clustering technique using average linkage method given in the SAS statistical package (SAS, 1987). Results of cluster analysis were used to identify soil physical constraints on coconut production.

Three lands from each soil series under similar management practices were selected and their nut yield during the 5-year period from 1988 to 1993 were used for the above statistical analysis.

\section{Physical properties}

For bulk density determination, undisturbed soil core samples were obtained using a steel core of $7.5 \mathrm{~cm}$ diameter and $5 \mathrm{~cm}$ in height. Soil water retention relationships were determined using core of $4.5 \mathrm{~cm}$ in diameter and $3.5 \mathrm{~cm}$ in height.

For soil water retention determination, undisturbed core samples were transferred to aluminum rings $(4.5 \times 3.0 \mathrm{~cm})$. These samples were saturated and water retention measurements were recorded using standard pressure plate apparatus for thirteen suction intervals ranging from 1 to $1500 \mathrm{kPa}$ (Klute, 1986). The gravimetric water contents at each suction level was estimated and converted to the volumetric water content using the corresponding bulk density values. The mean 
values of volumetric water content using the corresponding bulk density values. The mean values of volumetric water content between $10 \mathrm{kPa}$ and $1,500 \mathrm{Kpa}$ suction were used to calculate the percentage of available water fraction of all three soil horizons (Klute, 1986), of twenty soil series. Moisture depletion pattern was also estimated as a percentage of available water under different suction increments.

Hydrometer method was used for soil texture analysis. Total porosity was obtained using bulk density and particle density values. Particle density was assumed at $2.65 \mathrm{~g} / \mathrm{cm}^{3}$. Volumetric water content at saturation was estimated using porosity values. Water in pores which drained out at $10 \mathrm{kPa}$ (diameter $0.03 \mathrm{~mm}$ ) were estimated as macro pores and rest as micropores and soil particles (Danielson and Sutherland, 1986). Soil samples were taken at $5 \mathrm{~cm}$ depth intervals up to a depth of $1.3 \mathrm{~m}$ to determine the soil physical parameters. Six replicates were obtained from each depth of all exposed pits to characterize the above soil physical parameters.

\section{Morphological studies}

For the study on the effect of soil physical constraints on the morphological characteristics of coconut roots, plants grown in two soil series namely Madampe and Andigama were selected for representing the high and low productive soils, respectively.

Three months old coconut seedlings (just after root initiation) were exposed to three distinct soil horizons of Andigama and Madampe series namely, A, AB and B corresponding to 0-15, 15-50 and $50-150 \mathrm{~cm}$ depth respectively. Polythene sealed cement circle $(50 \mathrm{~cm}$ in diameter $\mathrm{x} 10 \mathrm{~cm}$ in height) were placed around each coconut seedlings in order to manage moisture level near root zone. A polythene cover around cement circle was used to minimize any effect of cement that may have on soil environment around seedlings. After one and half years of the establishment of seedlings in three horizons of both soil series, the water contents at three depletion levels viz. 10 to $30 \mathrm{kPa}, 10$ to 100 $\mathrm{kPa}$ and 10 to $1500 \mathrm{kPa}$ were maintained in order to create moisture stress around roots during the dry period.

Water retention curves and neutron probe readings were used to determine the time period required for water depletion from field capacity to moisture levels given above. The field capacity was maintained at $10 \mathrm{kPa}$, using tensiometers. The experiment was conducted for three months in the dry period followed by a field experiment using randomized block design with five replicates.

\section{Scanning electron microscopy (SEM)}

At the end of the experimental period, the absorption zone and root respiratory organs were carefully removed from the soil horizons. The epidermal layer of absorption zone was removed using a sharp blade. Respiratory organs and root tips were also removed from fresh roots. Samples were then fixed in $3 \%$ glutaraldehyde containing $3 \%$ acrolein in a $0.1 \mathrm{M} \mathrm{K}-\mathrm{K}$ phosphate buffer $(\mathrm{pH}=6.8)$ at room temperature for about 6 hours. Samples were then washed at $4^{\circ} \mathrm{C}$, using the same buffer as above and kept it overnight. Post fixing of tissues, was with $2 \%$ osmium tetroxide prepared in the same buffer as above at $4^{\circ} \mathrm{C}$. Tissues were then processed until suitable position for SEM study using method of Karnovsky (1965) and Spurr (1969).

SEM (SHIMADZU-EPMA $8705 \mathrm{~S}$, Electron probe micro Analyzer) was used for examination of the surface changes of roots and root-organs of coconut seedlings. Samples were mounted with double-sided tape on copper stubs. The mounted samples wee kept in a desiccator until ready for viewing on the SEM. The specimens were then, vacuum-coated with gold $(20 \mathrm{~nm})$. A "Cool" sputter coater (polar-roids) was used for vacuum coating (Davey, 1978). 


\section{RESULTS AND DISCUSSION}

\section{Effect of soil physical characters on coconut yield}

Multiple regression analysis with a backward and forward elimination procedure for determining the maximum $\mathrm{R}^{2}$ improvement for dependent variables with respect to coconut yield produced the following equation:

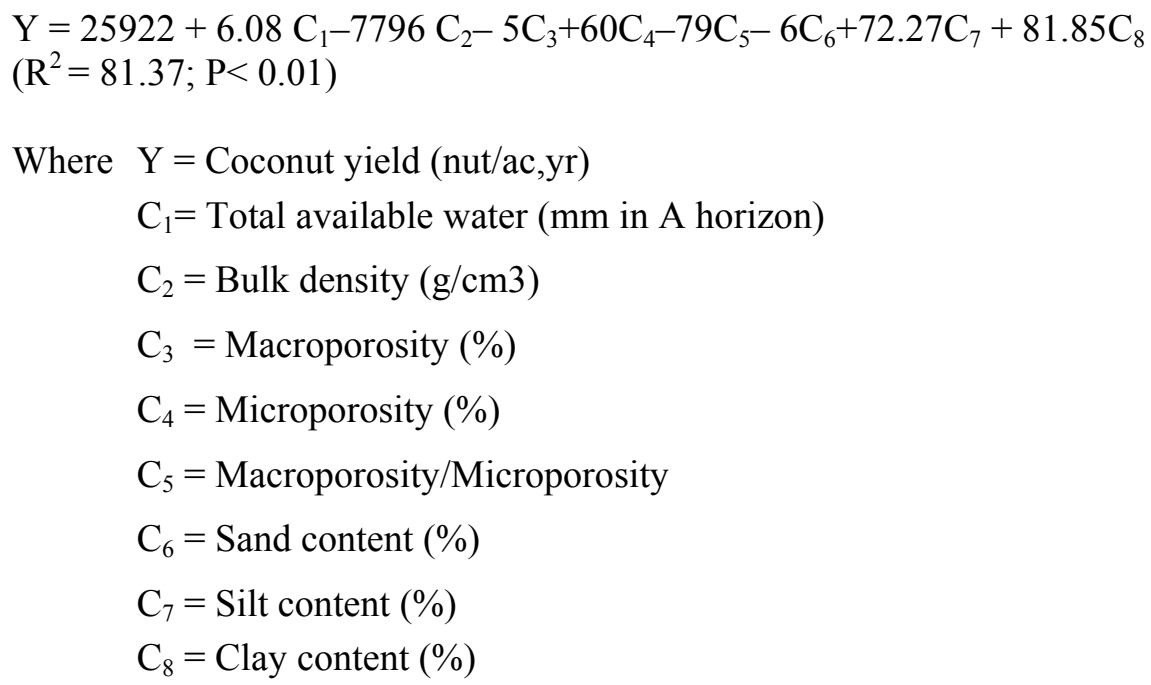

The $\mathrm{R}^{2}$ value for this equation is higher than that of soil horizons and this equation was found to be most reliable and accurate to evaluate the land characteristics on coconut yield. Gerard, et al., (1982) also followed a procedure similar to this and their results indicated that soil strength for different soils, at all depths, was influenced by bulk density, aeration and clay content.

The above equation clearly showed that total available water, \% of micropores and silt content showed a positive correlation $(\mathrm{P}<0.001)$ with coconut yield, while bulk density, macropores, proportion of macropores and \% of sand contents together showed a negative correlation $(\mathrm{P}<0.001)$ with coconut yield. This suggests that high compaction limited rooting depth of coconut seedlings. High amount of macropores could also reduce water retention in soil and leach mineral nutrient from effective root zone of coconut. Ultimately, this could badly affect coconut production. Also it appears that total available water and bulk density in soil series were the physical conditions that greatly affected the coconut yield. Identification of the optimum soil conditions for coconut production of each soil series is essential and is also important for a better understanding of the spatial variability of soil properties. In addition, the equation obtained using above statistical method, was found to be reliable and accurate in evaluation of the suitability of land characteristics on coconut production.

\section{Cluster analysis for land suitability}

Soil physical properties of the soil profiles of twenty soil series were mainly clustered into three groups with different dissimilarly co-efficient (Fig. 1). They are Andigama, Kalpitiya, Kurunagela, Maho, Wariyapola, Welikatiya, Sudu and Kalpitiya in group (1) as low productive, Welipalassa, Pallama, Madampe, Rathupasa and Katunayake in group (2) as moderately productive and Ambakele, Melsiripura, Gambura, Wilpattu, Mavilu and Borupan in group (3) as high productive soil series, respectively.

Physical properties of soil series indicated under group (2) and (3) were found to be suitable for growth and development of coconut. Somasiri et al., also assessed land suitability for coconut production based on morphological characteristics together with climatic, hydrological and land form 
considerations. The result of the present study was complementary to their assessment. Furthermore, soil series of the above three groups were clustered into different minor groups according to their specific characters. These observations clearly indicated that soil physical properties of Ambakele, Melsiripura, Gambura, Wilpattu, Mavillu and Borupan series are superior to those of Andigama, Kuliyapitiya, Kurunegala and Boralu series which are gravelly and known to be worst soil series for coconut cultivation due to their high compaction which limits rooting depth and water and nutrient absorption. Quisenberry et al., (1993) also identified the major soil constraints and they grouped soil into different classes using similar cluster analysis to evaluate the water and chemical transport process through soil profile. In addition, soil physical properties of Welipalassa, Pallama, Madampe, Rathupasa and Katunayake series were also yielding favorable conditions to enhance coconut production.

\section{Identification of major soil physical constraints}

Soil physical properties vs coconut yield with maximum R2 fitted cluster groups I and II given in Tables 1 and 2. It can be seen that low availability of water and high bulk density $(>1.5 \mathrm{~g}$ $\mathrm{cm}^{3}$ ) are the major physical constraints on coconut production. Total available water (TAW) less than $88 \pm 17 \mathrm{~mm}$ in the effective root zone is not favorable for coconut production. Further, TAW of soil higher than $190 \pm 16 \mathrm{~mm}$ under low bulk density $\left(<1.5 \mathrm{~g} / \mathrm{cm}^{3}\right)$ seem to provide better conditions for coconut production. It was found that higher total available water $(>300 \mathrm{~mm})$ and lower bulk density $(<1.4 \mathrm{~g} / \mathrm{cm} 3)$ provide highly favorable conditions for coconut cultivation. Boone and Veen (1994) also found that higher available water $(>240 \mathrm{~mm})$ and less than $1.56 \mathrm{~g} / \mathrm{cm} 3$ bulk density of Pullman soil (fine, mixed thermic Torrertic paleustolls) resulted in increasing corn yield. In addition, a considerable proportion of clay with silt about $(26 \pm 9 \%)$ and sand about $(75 \pm 7 \%)$ provided better condition for nutrient retention and aeration. These conditions also provide suitable pore size arrangement. Under these circumstances the volume of macroporosity, microporosity and their proportions were about $24 \pm 0.14 \% \$, 25 \pm 9 \%$ and $1.05 \pm 0.4 \%$, respectively. It can be seen that at least mean values of physical characters of cluster group (1) are essential for coconut production, while physical characteristics of cluster group (2) are not suitable (Tables $1 \& 2$ ). Simmons et al., (1989) reported that the efficiency of different soil properties on corn yield production varied under different landscape position. These physical constraints should be improved with appropriate agronomical practices under suitable management practices to optimize coconut production. High soil compaction $\left(>1.5 \mathrm{~g} / \mathrm{cm}^{3}\right)$ directly limits the available water in the coconut root zone and these limitations can be overcome by introducing low cost, in the long term profitable and eco-friendly agronomic methods such as (a) introducing of nitrogen fixing tree species as nitrogen fixing tree species inter-planted coconuts were found to be more effective in improving the soil physical conditions of degraded soils (Vidhana Arachchi and Liyanage, 1998) and (b) establishing suitable drip irrigation system (Vidhana Arachchi, 1998) in coconut plantations.

In addition, the results of this study would be of importance in formulation of land suitability for coconut cultivation and also in making site-specific recommendations for cultural practices. Results of land suitability evaluation using soil physical parameters could also assist in identifying potential areas for coconut cultivation.

\section{Morphological characters of coconut roots}

\section{Absorption cells}

Scanning electron microscopic study on morphological characters of absorption cells showed that production of more inactive roots are induced by soil low availability of water at the suction level of $10 \mathrm{kPa}$ due to compaction of soils (bulk density more than $1.5 \mathrm{~g} / \mathrm{cm}^{3}$ ) as a result of suberization and dehydration processes (plates $1 \mathrm{a}$ and $1 \mathrm{~b}$ ). These processes may also be enhanced due to changes in soil strength with drying or possibly with shrinking and swelling of soil (Alan, 
1991). Results also showed that water stress (suction $10 \mathrm{kPa}$ to $1500 \mathrm{kPa}$ treatments) reduced the cell volume per unit area of the absorption zone of coconut resulting in a retardation of water and nutrient absorption. These morphological changes in turn could adversely affect the nutrient and water absorption processes and this would result in retardation of the growth and development of plant (David, 1991). Reduction of cell volume resulted in increase of number of cells per unit area (plate 1a). Reduction in thickness of cell walls and cell volume is an indication of degree of soil physical stresses undergone by coconut seedlings grown in low productive soils such as Andigama series (plates 1a and1b) compared to that of high productive soils such as Madampe series (plate 1c). This could be attributed to low aeration capacity, readily available water retention and higher bulk density of soils of low productive soils. Vidhana Arachchi (1996) showed that results of root damage due to water stress caused by soil compaction limits the active zone of coconut roots. Kristina and Janine (1991) reported that the resistance to water flow from soil to roots is highly affected by the age of the root, by the degree of their development, by the magnitude of their suberization, and by the resistance of their endodermis. Wilson and Robards (1978) reported that in roots subjected to mechanical impedance, $90 \%$ of the endodermal cells had suberin lamellae only at a distance of $15 \mathrm{~cm}$ from the root apex. Such an anatomical change could have serious implications on water and nutrient uptake.

\section{Respiratory organs}

Respiratory organs are considered to be of great importance to the physiological function of coconut roots. Growth and function of these organs are known to depend on soil environmental factors. Study of the effect of soil characters on the morphological feature of respiratory organs can be useful in understanding the effect of soil characters on the function on respiratory organs.

SEM study on the effect of soil physical stress specially that of bulk density higher than 1.6 $\mathrm{g} / \mathrm{cm} 3$ (compaction higher than $250 \mathrm{~N} / \mathrm{cm}^{2}$ ) on the morphological features of respiratory organs of coconut are shown in plate $2 \mathrm{a}$ and $2 \mathrm{~b}$. Fine morphological features of respiratory organs can be seen in plate 3; they are oval in shape with a large number of holes. Holes of these oval shaped miniorgans are thought to be responsible for exchanging gases between the soil environment and roots.

Respiratory organs with most well developed micro-structure were observed in high productive soils such as Madampe series (plate 3). The high aeration capacity of highly productive soils could be the reason for well developed structure of respiratory organs. On the other hand, the microstructure of respiratory organs in low productive soils such as Andigama series was found to be damaged, presumably due to higher soil compaction (plates 2a and 2b). Davis (1968) reported that the number of respiratory organs decreased with increasing depth of the soil profile.

Crop growth is less than its potential when the uptake of water, oxygen or nutrient is less than the demand of the crop. This may be caused by a limiting activity of root system, or a limitation in length of the growing period (Boone and Veen, 1994). Soil compaction has been described as one of the major constraints which limit the water absorption and gas exchange process (Soane and van Ouwerkerk, 1994; Vidhana Arachchi et al. 1997).

\section{ACKNOWLEDGEMENTS}

Authors wish to thank the Director, Coconut Research Institute for giving permission in conducting this study, Mr. S K Gunarathna and Mr. K R E M Fernando for their assistance. Thanks are also extended to Messrs. H P Asoka Kumara, Pemsiri Silva and K L Ranasinghe for preparation of photographs. Financial assistance by the Council for Agricultural Research Policy for research grant number 12/175/149 is also acknowledged. 


\section{REFERENCES}

ALAN, T P B 1991 Growth and mechanical impedance. In plant and roots. (eds Voav Waisel, Amram Eshel and Uzi kafkafi) Publ. marce Dekker, INC. USA pp 393-414

BOONE, F R and VEEN, B W 1994 Mechanism of crop response to soil compaction. In soil compaction in crop production (Eds. Soane, B.D. and Ouwerker C. Van). Publ. Elsvier Science, New York. pp. 237-264.

CHILD, R. 1974. Coconut, Second Edition, Longman group Limited. pp 40-41

DANIELSON, R E and SUTHERLAND, P 1986. Porosity. In Methods and soil Analysis. Part 1, $2^{\text {nd }}$ Ed. ASA Monograph 9. (Ed. A Klute). Am. Soc. Agron. Wisconsin, USA. Pp. 443-460

DAVIS, T A 1968 A study on the respiratory organs of Cocos nucifera Linn. Ceylon Cocos, Quart. 3. $116-136$

DAVEY, B G. 1978 Soil structure as revealed by electron microscopy. In modification of soil structure ( W.W. Emerson, R.D. Bood and A R Dextar eds.), New York. John Wiley and Sons Publ. pp 97-102

DAVID, T C 1991 Root structure and sites of ion uptake. In Plant and Roots (Yoav Waisel, Amram Eshel and Uzi kafkafi eds.) New York. Marcel Dekker Publ. pp 417-425

FAO, 1977. Guideline for soil profile description, Food and Agriculture Organization of the United Nations, Rome.

GERARD, C J, SEXTON P and SHAW G 1982. Physical factors influencing soil strength and root growth. Agronomy Journal 74: 875-879.

JAYASEKARA, C 1990. Some notes on coconut root system. Coconut Bulletin Vol. 7 No. 1 / 2 5-7

KARNOVSKY, M J 1965. A formaldehyde-glutaraldehyde fixative of high osmolality for use in electon microscopy. J. Cell Biol. 27: 137-138

KLUTE, A 1986. Water retention: Laboratory methods. In Methods of soil Analysis Part $1.2^{\text {nd }}$ Ed. ASA Monograph 9. (Ed. A Klute) Am. Soc. Argon. Wisconsin, USA pp. 425-441.

KRISTINA, A V and JANNIE, B 1991. Tree root turnover and senescence. In Plant and Roots (Yoav Waisel, amram eshel and Uzi kafkafi eds.). pp. 287-306. New York. Marcel Dekker Publ.

PEIRIS, T S G and THATTIL, R O 1998. The study of climate effects on the nut yield of coconut using parsimonious models. Expl. Agric. 34: 189-206.

QUISENBERRY, V L SMITH, B R; PHILLIPS, R E; SCOTT H D and NOORTICLIFF S 1993. A soil classification system for describing water and chemical transport. Soil Sci. 156: 306315

SAS/STAT 1987. Guide version 6 edition. U.K.

SIMMONS, F W; CASSEL, C K and DANIELS, R B 1989 Landscape and soil property effects on corn yield response to tillage. Soil Sci. Sco. Am. J 53: 534-539. 
SOANE, B D and VAN OUWERKERK 1994. Soil compaction problems in World Agriculture. In Soil Compaction in crop production (Eds. Soane B D and Ouwerkerk C Van ) Publ. Elsvier Science, New York. pp. 237-264.

SOMASIRI, L L W; NADARAJAH, N; AMARASIRI, L and GUNATHILAKE, H A. 1994. Land suitability assessment of coconut survey area in the coconut triangle (eds. C R Panabokke and Mahindapala, R). Publ. The Coconut Research Institute, Sri Lanka.

SPUR, A R 1969. A low-viscosity epoxy resins embedding medium for electron microscopy. $J$. Ultrastructure. Res. 26: 31-34.

VIDHANA, ARACHCHI. L P. 1996. Characterization of physical properties of soils and studies on the development of coconut roots. The project report (12/175/149) submitted to the Council for Agricultural Research Policy (CARP), Sri Lanka.

VIDHANA, ARACHCHI L P; SOMAPALA, H; MAPA, R B and YAPA, P A J 1997 Study of the effective root zone of coconut in relation to soil compaction. Annual Sessions of the Sri Lanka Association for the Advancement of Sciences, Nov. 28, Kelaniya, Sri Lanka.

VIDHANA, ARACHCHI L P; (1998) Preliminary requirements to design a suitable drip irrigation system for coconut (Cocos nucifera L. ) in gravelly soils. Agricultural Water Management, 1390: $1-12$

VIDHANA, ARACHCHI L P and M de S LIYANAGE (1998). Soil physical conditions and root growth in coconut plantations interplanted with nitrogen fixing trees in Sri Lanka. Agroforestry systems, 39: 305-318.

WILSON, A J and ROBARDS, A W. 1978. The ultrastructural development of mechanically impeded barley roots: effects on the endodermis and pericycle. Protoplasm II 61-72. 
Table l. Mean Soil physical properties and standard error with maximum $\mathbf{R}^{2}$ fitted cluster group (1)

\begin{tabular}{|c|c|c|c|c|c|c|c|c|c|}
\hline $\begin{array}{l}\text { Soil series \& minor cluster } \\
\text { groups under major cluster } \\
\text { group (1) }\end{array}$ & $\begin{array}{l}\text { TAW } \\
(\mathrm{mm})\end{array}$ & $\begin{array}{c}\mathrm{BD} \\
\left(\mathrm{g} / \mathrm{cm}^{3}\right)\end{array}$ & Macp (\%) & Nlicp (\%) & Mac/mic & Sand $(\%)$ & Silt (\%) & Clay (\%) & $\begin{array}{l}\text { Silt }+ \\
\text { Clay }(\%)\end{array}$ \\
\hline $\begin{array}{l}\text { (i) } \\
\text { Andigama, Kuliyapitiya } \\
\text { Kurunagala, Boralu }\end{array}$ & $79.8 \pm 11.6$ & $1.55 \pm 0.03$ & $24.5 \pm 1.55$ & $17.65 \pm 2.31$ & $1.43 \pm 0.23$ & $75.7 \pm 5.1$ & $8.8 \pm 2.5$ & $16.16 \pm 4.7$ & $24.96 \pm 3.97$ \\
\hline (ii) & $108.24 \pm 3.5$ & $1.54 \pm 0.007$ & $17.3 \pm 3.7$ & $24.85 \pm 3.6$ & $0.718 \pm 0.26$ & $75.88 \pm 4.93$ & $0.32 \pm 3.15$ & $8.95 \pm 2.47$ & $23.88 \pm 0.68$ \\
\hline $\begin{array}{l}\text { (iii) } \\
\text { Welikatiya, Stidu, Kalpitiya }\end{array}$ & $76.7 \pm 25$ & $1.42 \pm 0.005$ & $40.32 \pm 1.57$ & $5.84 \pm 1.1$ & $7.1 \pm 1.4$ & $91.7 \pm 2.72$ & $2.72 \pm-1.6$ & $5.81 \pm 2.9$ & $8.59 \pm 1.72$ \\
\hline $\begin{array}{l}\text { Mean values for major } \\
\text { cluster group (1) }\end{array}$ & $88.25 \pm 17.4$ & $1.50 \pm 0.07$ & $27.37 \pm 11.8$ & $16.1 \pm 9.6$ & $3.08 \pm 3.49$ & $81.1 \pm 9.2$ & $8.82 \pm 6.1$ & $10.3 \pm 15.3$ & $19.14 \pm 19.2$ \\
\hline
\end{tabular}

Table 2. Mean soil physical properties and standard error with maximum $\mathbf{R}^{2}$ fitted cluster group (2)

\begin{tabular}{|c|c|c|c|c|c|c|c|c|c|}
\hline $\begin{array}{l}\text { Soil series \& minor cluster } \\
\text { groups under major cluster } \\
\text { group (1) }\end{array}$ & $\begin{array}{l}\text { TAW } \\
(\mathrm{mm})\end{array}$ & $\begin{array}{c}\mathrm{BD} \\
\left(\mathrm{g} / \mathrm{cm}^{3}\right)\end{array}$ & $\operatorname{Macp}(\%)$ & Nlicp (\%) & Mac/mic & Sand (\%) & Silt (\%) & Clay (\%) & $\begin{array}{c}\text { Silt }+ \\
\text { Clay }(\%)\end{array}$ \\
\hline $\begin{array}{l}\text { (iv) } \\
\text { Welipalassa, Pallama, } \\
\text { Madampe, Rathupasa } \\
\text { Katuilayake }\end{array}$ & $191.3 \pm 16.7$ & $1.48 \pm 0.04$ & $33.1 \pm 3.4$ & $11.56 \pm 3.2$ & $3.1 \pm 1.03$ & $84.7 \pm 4.2$ & $3.35 \pm 1.9$ & $10.68 \pm 2.04$ & $14.03 \pm 2.9$ \\
\hline $\begin{array}{l}\text { (v) } \\
\text { Ambakelle, Melsiripula }\end{array}$ & $303.6 \pm 5-6$ & $1.36 \pm 0.25$ & $24.0 \pm 0.14$ & $24.6 \pm 9.3$ & $1.05 \pm 0.4$ & $75.3 \pm 8.5$ & $10.4 \pm 4.1$ & $15.85 \pm 5.6$ & $26.26 \pm 9.7$ \\
\hline $\begin{array}{l}\text { (vi) } \\
\text { Gambura, Wilpattu } \\
\text { Mavillu, Borupan }\end{array}$ & $260.12 \pm 19$ & $1.49 \pm 0.02$ & $31.45 \pm 5.6$ & $12.6 \pm 6.13$ & $2.88 \pm 2.9$ & $84.93 \pm 3.5$ & $5.48 \pm 2.14$ & $10.02 \pm 1.6$ & $15.40 \pm 3.4$ \\
\hline $\begin{array}{l}\text { Mean values for major } \\
\text { cluster group (2) }\end{array}$ & $251.7 \pm 56.6$ & $1.44 \pm 0.07$ & $29.52 \pm 4.9$ & $16.3 \pm 7.2$ & $2.34 \pm 1.13$ & $81.6 \pm 5.5$ & $6.41 \pm 3.61$ & $12.18 \pm 3.19$ & $18.56 \pm 6.7$ \\
\hline
\end{tabular}




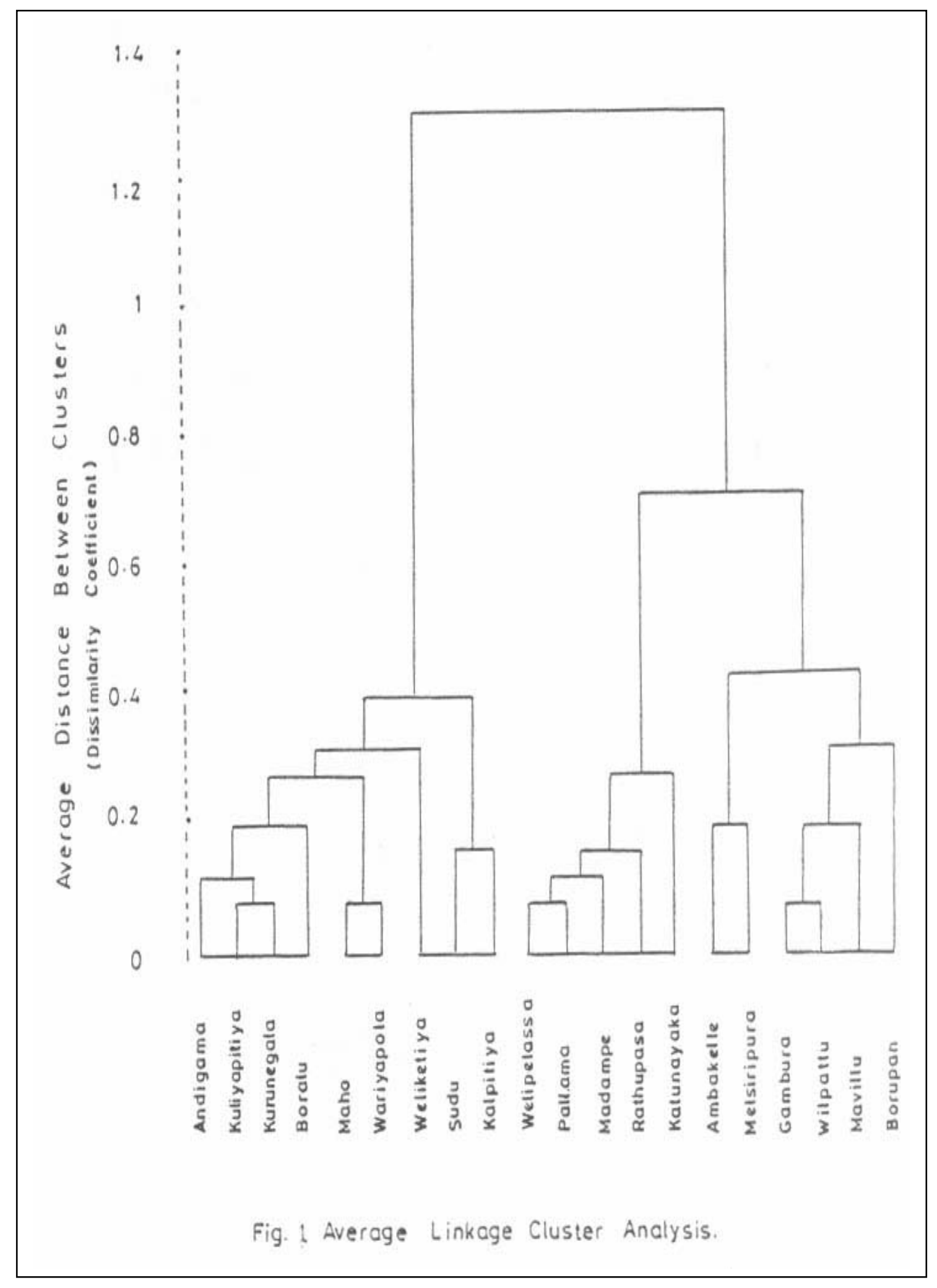



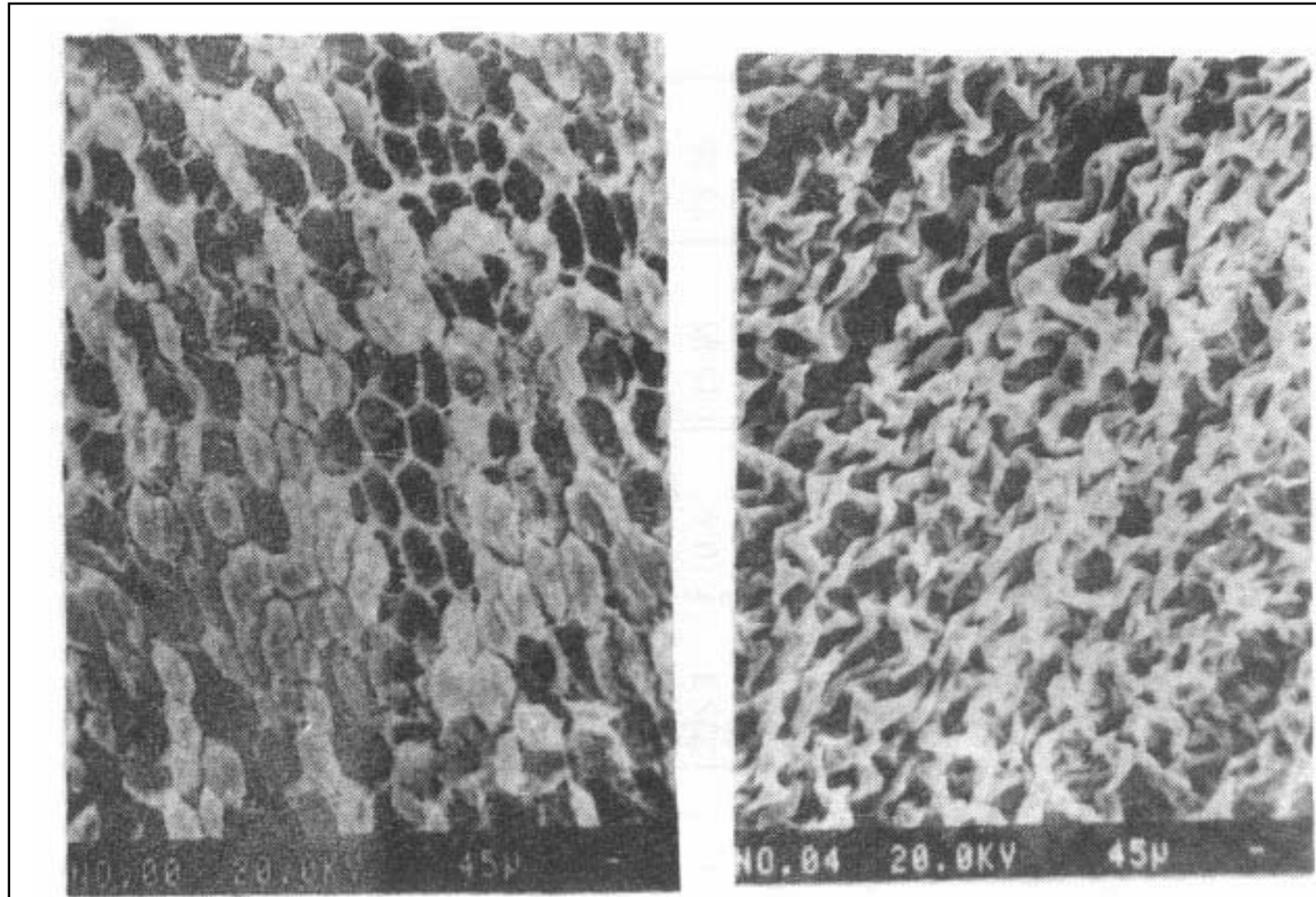

(a)

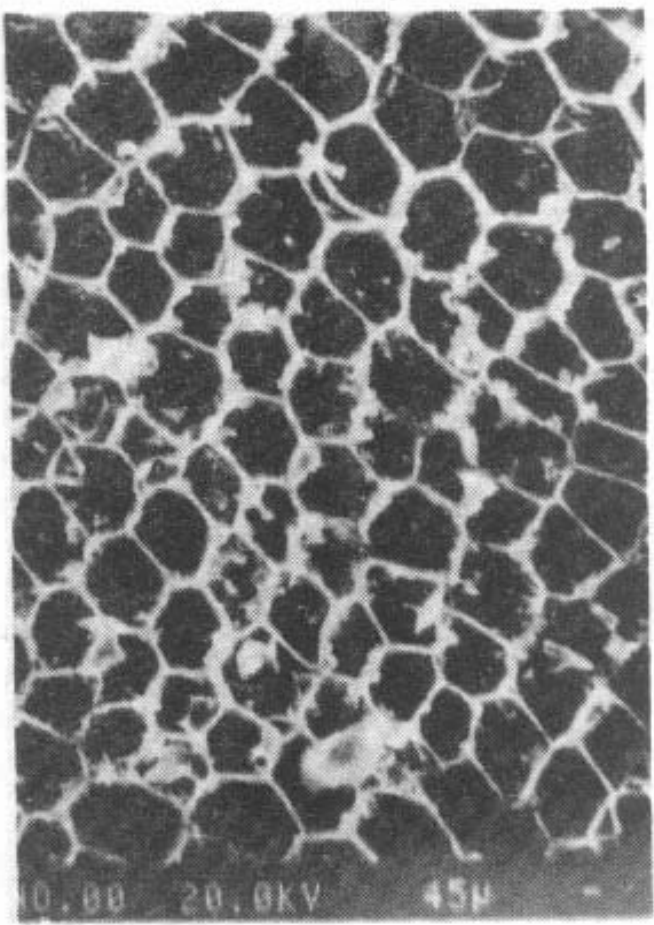

(b)

(c)

Plate 1. Suberized (a), dehydrated (b) and well developed (c) cells of absorption zone 


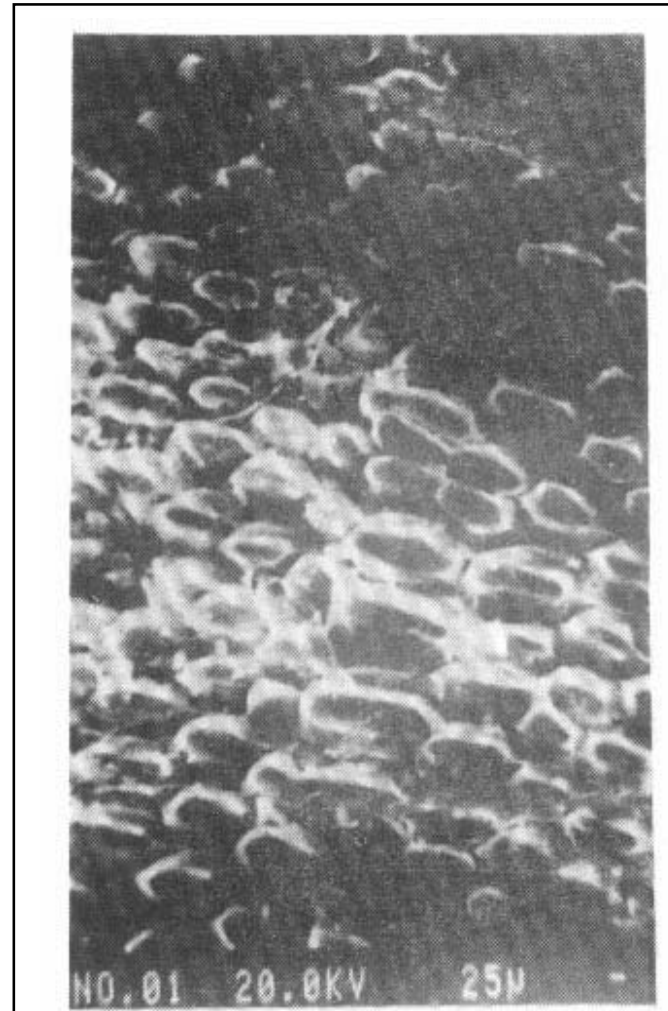

(d)

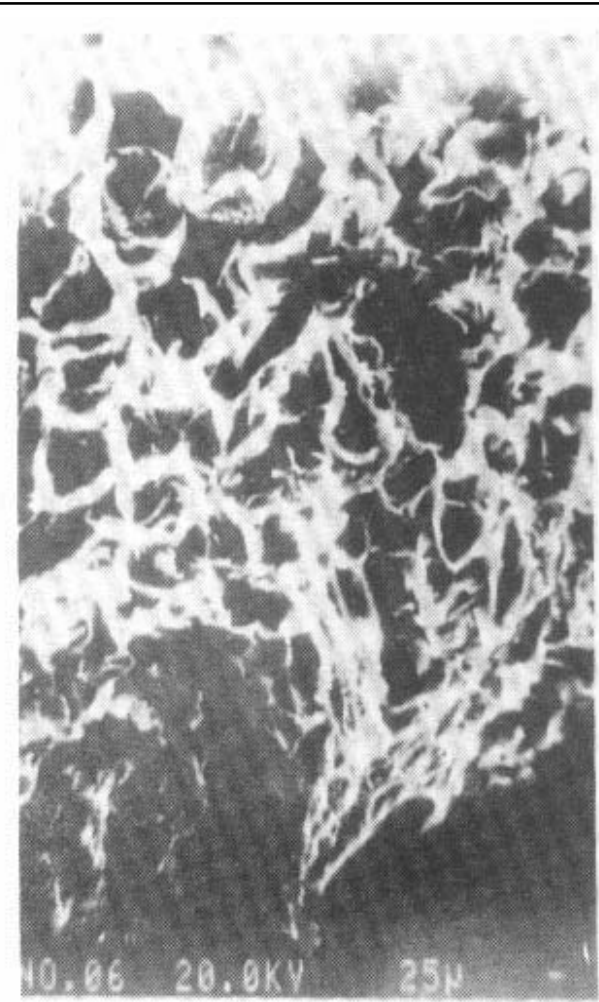

(e)

Plate 2. Damaged (d and e) respiratory organs under high soil compaction

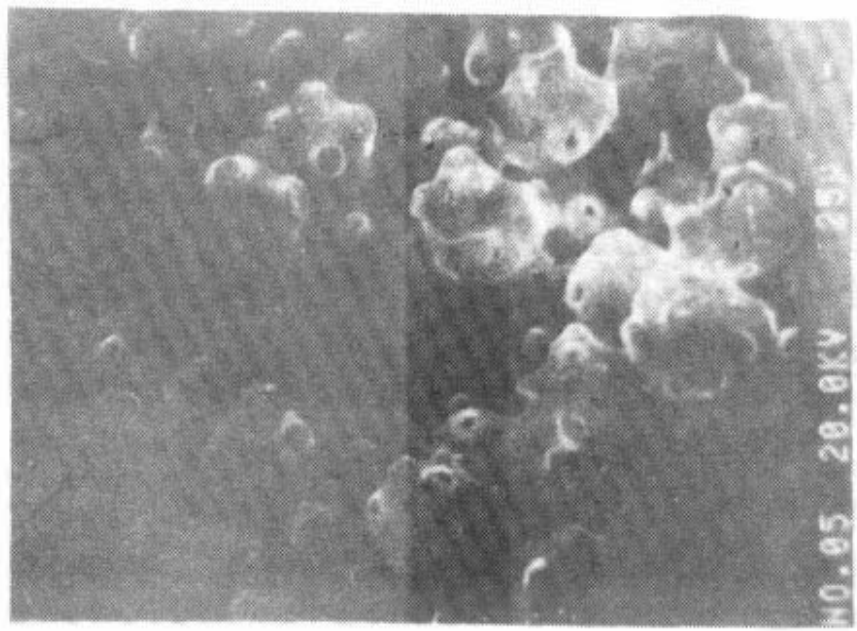

(f)

Plate 3. Well developed (f) micro-structure of respiratory organs 